\title{
Anti-epoetin-antibody-induced anemia in a child with chronic renal failure
}

\author{
Jasper J. Jöbsis • Karin Fijnvandraat • \\ Steven O. Stapel • Anthonia H. Bouts
}

Received: 11 December 2009 / Accepted: 16 December 2009/Published online: 18 February 2010

(C) The Author(s) 2010. This article is published with open access at Springerlink.com

\begin{abstract}
Sirs,
Recombinant human erythropoietin was introduced in 1988 for the treatment of anemia in chronic kidney disease (CKD). The development of antibodies against epoetin was a rare complication during the first decade of its use. However, in 1998 there was a sudden increase in epoetin-induced antibodies associated with pure red cell aplasia (PRCA) in patients with CKD who had been using Eprex, a subcutaneous epoetin-alfa product marketed in Europe [1, 2]. Although the recombinant epoetin products differ in glycosylation, the increase in PRCA was probably caused by a change in the formulation of Eprex in which human serum albumin was replaced by glycine and polysorbate 80 [3]. Switching patients from subcutaneous to intravenous administration and adding Teflon to the rubber stopper of prefilled Eprex syringes subsequently eliminated nearly all antibody formation. For epoetin-beta, antibody-associated PRCA is even rarer, as evidence by the very few cases that have been published. We present here the first report of a child who developed antibody-associated PRCA elicited by the use of epoetin-beta.
\end{abstract}

\footnotetext{
J. J. Jöbsis $(\square) \cdot$ A. H. Bouts

Department of Pediatric Nephrology,

Emma Children's Hospital-Academic Medical Centre,

Meibergdreef 9,

1105 AZ Amsterdam, The Netherlands

e-mail: j.j.jobsis@amc.nl

K. Fijnvandraat

Department of Pediatric Hematology, Emma Children's Hospital, Amsterdam, The Netherlands

S. O. Stapel

Sanquin Diagnostic Services,

Amsterdam, The Netherlands
}

The patient was born on the Dutch Antilles. In 2004, at the age of 5 years, he developed renal failure due to persistent obstructive uropathy. His CKD-related anemia was treated with epoetin-beta subcutaneously from 2004 onwards $(2 \times 2000 \mathrm{IE} /$ week $)$. After 1.5 year of use, he developed a progressive transfusion-dependent anemia unresponsive to recombinant epoetin-beta (Neorecormon: maximum $5 \times 2000 \mathrm{IE} /$ week) and presented at our hospital (Fig. 1). An increase in the epoetin-beta dose to $5 \times 6000 \mathrm{IE} /$ week had no effect on the reticulocyte count, demonstrating that the anemia was unresponsive to epoetin-beta.

Laboratory testing revealed the following: hemoglobin (Hb), $2.8 \mathrm{mmol} / \mathrm{L}$; reticulocyt count, $<0.1 \%$; MCV, 83; white blood cells $(\mathrm{WBC}), 11.7 \times 10^{9} / \mathrm{L}$; platelet count, $228 \times 10^{9} / \mathrm{L}$. There were no signs of hemolysis: lactate dehydrogenase, $184 \mathrm{U} / \mathrm{L}$; haptoglobin, $0.99 \mathrm{~g} / \mathrm{L}$. The combination of anemia, low reticulocyte count, and normal leukocyte and trombocyte count with the use of epoetinbeta suggested a diagnosis of antibody-mediated PRCA. Anti-epoetin immunoglobulin (Ig) $G$ antibodies identified by means of an antigen binding assay, essentially as described by Aalberse et al. [4], were indeed elevated. Treatment was initiated with one pulse methylprednisolone (15 mg/kg), followed by prednisone $1 \mathrm{mg} / \mathrm{kg} /$ day, and cyclosporine $4 \mathrm{mg} / \mathrm{kg} /$ day (trough levels $50-100 \mathrm{mg} / \mathrm{l}$ ). Within days of starting this treatment, anti-epoetinantibodies levels declined and were undetectable after 2 months of treatment (Fig. 1). The reticulocyte count increased to $2 \%$ after 3 months, and from then on $\mathrm{Hb}$ remained at acceptable levels between 5 and $7 \mathrm{mmol} / \mathrm{L}$ without the need for blood transfusions (Fig. 1). After 3 months, the prednisone dosage was reduced to $7.5 \mathrm{mg}$ $(0.3 \mathrm{mg} / \mathrm{kg} /$ day $)$ and the cyclosporine dosage to $3 \mathrm{mg} / \mathrm{kg} /$ day until transplantation. One year later a successful family 


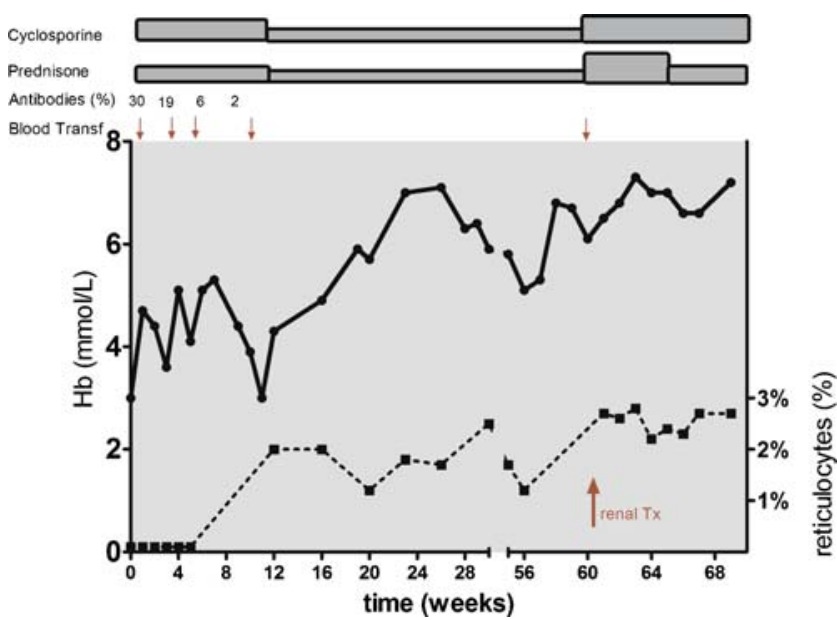

Fig. 1 Treatment regimen of progressive transfusion-dependent anemia unresponsive to recombinant epoetin-beta in our young patient with chronic kidney failure. $H b$ hemoglobin

kidney transplantation was performed, and $\mathrm{Hb}$ was stable at $6.5 \mathrm{mmol} / \mathrm{L} 4$ months after transplantation (Fig. 1).

This 5-year-old boy developed PRCA caused by antiepoetin-antibodies following exclusive treatment with epoetin-beta subcutaneously. The subcutaneous administration of epoetin may have rendered the immune system of this boy more susceptible to antibody formation.

Treatment options for antibody-associated PRCA are invariably based on case reports or case-series. Several immunosuppressive drugs have been tried: corticosteroids alone, cyclophosphamide, cyclosporine, mycophenolate mofetil, intravenous immunoglobulin, and anti-CD20 monoclonal antibodies, with or without corticosteroid treatment. Although the results of different strategies vary, all patients who had a kidney transplant showed a full recovery of erythropoiesis [5]. Our patient responded well to a pulse of methylprednisolone followed by prednisone and low-dose cyclosporine. After this treatment the $\mathrm{Hb}$ remained stable, indicating the permanent disappearance of antibodies. No side-effects of our treatment were noted, and a successful renal transplantation was ultimately performed.

In conclusion, the combination of prednisone and cyclosporine in a low dose was successful in the treatment of anti-epoetin-antibody-induced anemia in a child with chronic renal failure.

Open Access This article is distributed under the terms of the Creative Commons Attribution Noncommercial License which permits any noncommercial use, distribution, and reproduction in any medium, provided the original author(s) and source are credited.

\section{References}

1. Casadevall N, Nataf J, Viron B, Kolta A, Kiladjian J, MartinDupont P, Michaud P, Papo T, Ugo V, Teyssandier I, Varet B, Mayeux P (2002) Pure red-cell aplasia and antierythropoietin antibodies in patients treated with recombinant erythropoietin. $\mathrm{N}$ Engl J Med 346:469-475

2. Macdougall IC (2005) Antibody-mediated pure red cell aplasia (PRCA): epidemiology, immunogenicity and risks. Nephrol Dial Transplant 20(Suppl 4):iv9-iv15

3. Schellekens H (2005) Immunologic mechanisms of EPO-associated pure red cell aplasia. Best Pract Res Clin Haematol 18:473-480

4. Aalberse RC, van der Gaag R, van Leeuwen J (1983) Serologic aspects of IgG4 antibodies. Prolonged immunization results in an IgG4-restricted response. J Immunol 130:722-726

5. Verhelst D, Rossert J, Casadevall N, Kruger A, Eckardt KU, Macdougall IC (2004) Treatment of erythropoietin-induced pure red cell aplasia: a retrospective study. Lancet 363:1768-1771 